UDC 811.111'37

DOI https://doi.org/10.24919/2308-4863/39-3-17

\author{
Anastasiia SKICHKO, \\ orcid.org/0000-0003-4888-3159 \\ Postgraduate Student, \\ Lecturer at the Department of Theory and Practice of English Translation \\ National Technical University of Ukraine "Igor Sikorsky Kyiv Polytechnic Institute" \\ (Kyiv,Ukraine) anastasiia.skichko@gmail.com
}

\title{
THE CONCEPT OF MOTIVATION TAXONOMY FROM THE PERSPECTIVE OF COGNITIVE LINGUISTICS AND PSYCHOLOGY
}

The article describes different approaches to define the concept of MOTIVATION from the perspective of psychology and cognitive linguistics as well as its characteristics and way of verbalization is examined. The concept of MOTIVATION includes the psychological aspect of information perception through language, emotions, appearance, temper and nonverbal means of communication. The purpose of this article is to examine the correct taxonomy of this concept, distinguish its typological features, etymology and possible ways of realization in oral speech.

The concept of MOTIVATION can be determined as basic, simple in its structure, a spiritual phenomenon that can be realized through various phrases, sentences, texts, types of discourse, images and schemata. Moreover, it is idioconcept because each person understands and interprets this notion through his own world perception. The term motivation itself comes from Latin language and includes the root «moteve» which means «to move forward».

Because of the linkage between psychology and linguistics the concept of MOTIVATION can be very easily verbalized in the linguistics picture of the world through various contexts and communication situations. Motivation itself presents in every aspect of human life as well as each person can have it. If we divide our life into several important domains, people need some stimulus to move forward to earn the desired aim. Over time this notion was modified from only psychological terms to universal, but every person attaches only its unique significance to it. Taking into account this knowledge, it is necessary to identify the sources that can awake the inner energy to act.

Key words: cognitive linguistics, psychology, concept, motivation, oral communication.

Анастасія СКІЧКО, orcid.org/0000-0003-4888-3159 аспірантка, викладач кафедри теорії і практики перекладу англійської мови Національного технічного університету Украӥни «Київський політехнічний інститут імені Ігоря Сікорського» (Київ, Україна) anastasiia.skichko@gmail.com

\section{ПОНЯТТЯ МОТИВАЦЙНОЇ ТАКСОНОМІЇ З ПЕРСПЕКТИВИ КОГНІТИВНОЇ ЛІНГВІСТИКИ ТА ПСИХОЛОГІї}

У статті розглядаються різні підходи до визначення концепту МОTIVATION з огляду психології та когнітивної лінгвістики, а також досліджуються його характерні риси та способи вербалізащії. Концепт MOTIVATION базується на психологічному аспекті сприйняття інформаџії через мову, емоції, зовнішній вигляд, вдачу та невербальні засоби спілкування. Мета даної статті полягає у формуванні коректного визначення иього поняття, виокремленні типологічних особливостей, дослідженні його походження та можливих способів реалізаиї в усному мовленні.

Концепт MOTIVATION є базовим, простим за своєю структурою, духовним явищем, яке вербалізується за допомогою вільних фраз, речень, текстів, типів дискурсу, образів і схем. Більше того, це - ідіоконцепт, оскільки кожна людина розуміє та інтерпретує иче поняття через власне світобачення. Сам термін «мотивація» походить з латинської мови і включає корінь «тотеvе», щзо означає «рухатися вперед».

Через зв'язок між психологією та лінгвістикою кониепт MOTIVATION може бути легко виражений у лінгвістичній картині світу через різні контексти та ситуації спілкування. Мотивація присутня у кожному аспекті людського життя, як $і$ у кожної людини. У кожній сфері людина має чітко усвідомлювати стимул $і$ мати мотивацію для того, щзоб досягти успіху $і$ бажаної мети. 3 часом це поняття було змінено лише з психологічних термінів на загальнолюдське, але кожна людина надає йому лише своє унікальне значення. Беручи до уваги иі знання, необхідно виявити джерела, які можуть пробудити внутрішню енергію до дії.

Ключові слова: когнітивна лінгвістика, психологія, концепт, мотивація, усне спілкування. 
Statement of the problem. The globalization and computerization of the modern world are bringing about change in the language behavior of individuals, their manner of communication, processing and perception of received information, as well as in the conceptual picture of the world in general. Nowadays, the concept of MOTIVATION is extremely essential in the modern world, since the theoretical background of this phenomenon has already exposed and well-structured in psychology but not from the linguistics perspective. Moreover, the motivation of successful individuals as a psychological term in any field is of social interest. Each of us has a purpose and a goal, and motivation is present in each implemented action. This phenomenon continuously accompanies individuals throughout all life.

Research analysis. Cognitive linguistics is regarded as a relatively young field of modern linguistics studies, but it possesses a great variety of innovative approaches that are able to find interdisciplinary connections between language and thoughts. It is based on the anthropological paradigm because at the core of this study is a human and his mental abilities to perceive and produce information. American cognitive linguist, Ronald Langacker, nominates the establishment of the Cognitive Linguistics Society in 1989 as the birth of a prospective, modern, innovative and fundamentally grounded intellectual direction (R. W. Langacker, 1991). The Slavic scientific school (Ukrainian, Russian, Poland) continued to develop this movement and provoked a splash of new views from the perspective of Slavic mentality and picture of the world during the last three decades.

The Polish school is represented by A. Wierzbicka (A. Wierzbicka, 1992), Elżbieta Tabakowska (E. Tabakowska, 2010), Barbara LewandowskaTomaszczyk (B. Lewandowska-Tomaszczyk, 2016), Ewa Dąbrowska (E. Dąbrowska, 2015) who worked on the conceptualization concepts, searching connection between cognitive phenomenon and culture and giving a fresh view on the definitions, classifications and structure of basic cognitive notions.

The Ukrainian school of cognitive linguistics is characterized by prominent scholars like A.M. Prykhodko (A.M. Prykhodko, 2008), V.M. Manakin (V.M. Manakin, 2012), S.A. Zhabotynska (S.A. Zhabotynska, 2004), O.O. Selivanova (O.O. Selivanova, 2012), A.P. Martunyk (A.P. Martunyk, 2011) and others which simultaneously with the Russian scholars like U. S. Stepanov (U. S. Stepanov, 2007), V.I.Karasik(V.I.Karasik, 2002), S.H. Vorkachev (S.H. Vorkachev, 2004), M. V. Pimenova (M.V.Pimen- ova, 2013) and others have formed a fundamental background for the further studying of cognitive linguistics with a great theoretical and practical layout.

The purpose of the article is to describe the specifics, typology, etymology and general peculiarities of the concept of MOTIVATION and to discover its meaning from the psychological and cognitive linguistics perspectives in order to conduct valid further research in this domain.

Presenting main material. According to V. Evans and $\mathrm{M}$. Green, language serves not only to code and transfer messages from speaker to listener, but in a wider sense, it opens the gates towards the understanding of thoughts' structure, form and implication (V. Evans, M. Green, 2016: 50) If we consider the reproduction of speech from the very beginning, we can admit that firstly our mind composes ideas and thoughts over the exact topic and only after with the help of language apparatus we mechanically replicate logically related sentences. The most significant problem of each fundamental theory is the correlation between language and thinking as one of the essential mental processes. Not all theories can reveal and show in which manner and how language helps our mind to produce thoughts and verbalize them (R. Jackendoff, 1997).

The significant input to the development of cognitive linguistics was the publication of the book Metaphors We Live By issued by American scientists Lakoff G. and Johnson M. In 1980 (G. Lakoff, M. Johnson, 1980). They elaborated theory according to which all human beings possess the ability to discover the world and accumulate knowledge through sensory-mental apparatus, that in their opinion, is the most universal and efficient tool for conceptualizing embodied experience that is filtered through the cultural fond of each nation (G. Lakoff, M. Johnson, 1980: 14).

W. Croft, D. Lightfoot, D. Alan Cruse and others believe that language is a mechanism of representing well-structured, grouped and symbolic units in realtime based on the previous experience and each word has its own concepts, the wide pattern of meaning (W. Croft, and D. Alan Cruse, 2004: 1-7). Since the concept is introduced as a mental unit that has its own domain and is formed on previously earned experience, we can assume that word is a more restricted term. In terms of communication, the concept because of its multifaceted structure influences the manner of transmitting necessary language units regarding the contextual situation. To put it another way, this term is viewed as a well-organized fragment of personal and social experience that is denoted by different language units (J. R. Taylor, 2002: 43). 
U.S. Stepanov defines the term "concept" as an energy clot of culture that enables any verbal expression and communication to understand the surrounding world with the help of our sensory capabilities like hearing, feeling, smelling, touching and even tasting (U. S. Stepanov, 2007: 40).

Under the term «concept» we understand visual, thematic, well-grouped schemata that have a hierarchical structure with various interdependent layers that absorb personal, social and intersocial experience from former interaction with other representatives of humanity. In order to better understand this idea, let's imagine a blossoming tree. If we look at it, we will see stem - a key concept, that covers with bark - an individual perception of individuals. Out of the bark, it will be seen various branches and twigs - our experience of the future will be introduced in the form of buds - a verbal conceptualization. But there is one thing that we cannot see - a root, namely the mental and cultural background of the person, that is very individual.

The most interesting fact about concept function is that it is capable of visualizing images and scenarios from the former experience. M. Johnson is convinced that any words and their concepts are directly perceived and adopted by the human body (M. L. Johnson, 1987). For example, each conversation with different persons leaves its stump in the mind as well as the non-verbal movements of speakers. From this perspective, we can assume that during all our lifetime we earn verbal, visual, physical experience that unconsciousness embodies in our brain, which in further situations mechanically reproduces in the form of various structured concepts.

V. Evans differentiates primary and secondary lexical concepts. The first ones are more attached to the cognitive abilities to perceive and save information from the outer world in mind. While the second one includes only cultural elements, objects and details (V. Evans, 2004).

All concepts are realized in language with the help of different means like lexemes, phraseological units with appropriate semas, free phrases, sentences, schemas and texts (Z.D. Popova, Y.A. Sternyn, 2002: 38). Each concept contains extralinguistic knowledge and includes a great variety of means of an organization like frame, base, scene, schema, script, global pattern, pseudo-text, cognitive model, experimental gestalt (C.J. Fillmore, 1985: 223). Ukrainian scholar O.O. Selivanova proposes to divide all concepts according to subjects of conceptualization on idioconcepts that concern the person's mind, conventional concepts that include a certain group of people, ethnoconcepts that evolve behavior peculiarities of ethnic minorities and universal concepts that are common to humanity (O.O. Selivanova, 2012: 316). M.V. Pimenova develops an extended classification in terms of predominant elements and their meaning, she proposes to divide concepts into three categories: basic concepts that include space, social and psychological phenomena; descriptive concepts comprise dimensional, qualitative, quantitative notions; relative concepts contain evaluation, position and private components (M.V. Pymenova, 2013: 127-131). O. S. Kubriakova proposes to group all concepts into primary and secondary. The first group is impossible to interpret from the point of view of their meaning, while the concepts of the next group have undergone changes and were modified throughout time, dissimilar objects and subjects. Additionally, the researcher put forward the idea that according to the structure, there are the simple concepts that are represented in the language picture of the world with the help of one word, and complex concepts that need more verbal and emotional description over the sentence and text pattern (O.S. Kubriakova, 1996: 90-93).

With the continuous growth of the professional workers' potential on different world market domains, the concept of MOTIVATION is at peak of its popularity. The big enterprises hire special coaches that work with their employees in order to raise their stimulus and talents to efficiently reach the goals. A dozen people having a great desire to change their life for the better are in reach of inspiration to obtain new skills, learn new languages, lose weight, start a family or earn more money. Each human being on the planet Earth has their own stimuli in life that is formed according to their needs, character, social status and surroundings. Therefore, it will be a right statement that each of us lives possessing our own driven force, that is motivation.

The Merriam-Webster dictionary (Merriam-Webster dictionary) defines motivation as the condition that a person uses in order to earn a willingness to act. Most probably, the etymological origins of this word come from the Latin language since it contains the Latin root «movere» which means «to move forward». Nevertheless, there are assumptions that it could be modeled on French «motiver» or German «motivieren». This term was firstly used in 1873 and possessed the next meaning «act or process of furnishing with an incentive or inducement to action» (Online etymological dictionary). However, there is another hypothesis that Latin word «movere» comes from the Proto-Indo-European word «mew» that has two meanings: «to wash» and «to be or become wet». Out this root a lot of derived words composed with practically the same meaning: mōmentum «movement», mōtio «motion», mūtō «remove», per- 
moveō «agitate», mōtō «bike», «motorcycle», mōtor «engine», etc. (Word Sense Dictionary). Observing all these examples it is seen that in their etymological structure inherent similar value «to make an effort in order to ensure continuous forward movement». Nevertheless, Centre National de Ressources Textuelles et Lexicales in France is convinced that the root of this notion «motif» existed a long time ago before 1873. They fixed the first usage of this word jointly in collocation «justified by the motives» in juridical documents in 1721 (Ortolang).

MOTIVATION has long been studied in psychology by different researchers like Bandura (1986), Gorman (2004) and many others. Motivation is regarded as goal-oriented behavior, which is introduced by the complex mental process that induces a person to take action towards the concrete situation. Before taking decisions our brain weighs all pros and cons, in one world the cognitive factors switch (P. Gorman, 2004: 1-2). Similarly, A.Bandura under the term motivation understands certain unconscious attempts to reveal which driven force influences on choosing the way, selection methods, elaboration of strategy and making people reach their goals during a certain period of time (A. Bandura, 1991: 69).

The approaches towards motivation define as many as scholars, some of them like Stanovich think that there is a universal truth that this term not only includes individual and unique interpretations but also «folk wisdom» (K.E. Stanovich, 2013: 13). In other words, people's motivation is interpreted not only deeply by individual perception and feelings but also collective knowledge and real examples. These previously mentioned interpretations relate to the key definition of motivation in psychology science, in our opinion, that is the following intensity and a certain level of attempts conduct straightforward to the goal attached to the learning process (B. Hoffman, 2015: 8). Particularly the main rule of getting desired lies throughout the continuous and long-lasted procedure of studying.

In 1985 Deci and Ryan introduced self-determination theory, which proclaims two basic types of motivation - intrinsic and extrinsic. Intrinsic motivation concerns the actions that give you pleasure, so the person has a strong desire to do something and instead to earn an internal award. While extrinsic motivation does not refer to satisfying the physiological needs and its main aim is to receive an external reward like money, house, car, etc (E. L. Deci, R. M. Ryan, 2000: 70-73).

Maslow (A.H. Maslow, 1970), taking into consideration biological human needs, developed a wellknown motivational theory that looked like a pyramid, consisting of five inter-depended levels:
- self-actualization: morality, creativity, problemsolving;

- esteem: confidence, achievement, respect of others;

- love/belonging: friendship, family, sexual intimacy;

- safety: security of body, of employment, of resources;

- physiological: breathing, food, water, sex.

This classification was very popular among scholars for several decades, there were a lot of discussions over it, but nowadays this theory is not so prominent as before. Because life has changed so much with time as well as a people's priorities and this hierarchy can be preserved anymore.

As we can observe, the concept of MOTIVATION is in the area of psychology's scientific interest and it has a well-established theoretical background. What concerns the investigation of this term in the scope of linguistics, the first scholar who embodied the term «motivation» was Ferdinand de Saussure. He developed the semiotic principles of the arbitrariness of the linguistic sign and stated that in the modern world each language is motivated to some extent, but at the same time, it is hard to find at least ones where all elements are motivated. Therefore, it cannot be excluded that a dozen diversities exist between minimized organization and arbitrariness (F. de. Saussure, 1916/1959: 133). What is more, Saussure observes the linguistic sign as a mental indivisible entity that possesses its own defined content linked to its acoustic image (F. de. Saussure, 1995: 99).

Radden and Panther view motivation as the oneside correlation of two important elements: linguistic source and target (G. Radden, K.-U. Panther, 2004: 4). Lakoff developed the idea that the lexical vocabulary of each human being is a well-organized system of knowledge and in this conceptual system, most linguistics units are motivated to its possible degree in various aspects. He also proposes a hypothesis that within every word exist motivational links that logically relate three notions: the units form and meaning and lexical senses (G. Lakoff, 1987: 346, 452). To conclude, the motivation in linguistics is learned through the prism of semiology, lexicology and grammar fields.

The verbalization of the concept of MOTIVATION in the scope of cognitive linguistics and linguoculturology, its structure and realization in the English picture of the word, specifically in public speeches is our prime scientific interest since no studies of this type have been conducted so far and this concept is needed to be studied because of its popularity and meaningful context. From our perspectives, the concept of MOTIVATION is the basic concept in cognitive linguistics, 
which is inherent to every living being and viewed from individual retrospectives, that have a branched structure because of unlike character, temper, world perception and various domain of realization in different field of human life like education, work, sport, personal relationship, family and friends.

All in all, this concept is present in all linguistic cultures, especially in Western ones, and has regular verbalization through formal and informal communication. It is a primary lexical concept as long as it has a linkage to perceive the information from the outer world, accumulate it and keep it in mind in the form of schemata, scenarios, or images that reaffirm the obtained experience in the past.

The concept of MOTIVATION is a simple one because it contains the main lexeme, namely root «motive» to which the non-productive suffix «tion» is attached. In the Online Dictionary, it is said that such type of suffixes most probably comes from Latin origin that was used in order to change one part of speech into another one, in this case, verb into abstract nouns. Subsequently, by learning the etymological background of the word «motivation» we can state that its origin is a Latin language and during the evolution process the French language inherited its meaning (Online Dictionaries. Word Reference)

According to its realization in language, the concept of MOTIVATION can be apprehended throughout free phrases, sentences, schemas and texts. However, to our point of view, when the researched concept is verbalized only through phrases or sentences, we can observe the full picture of it, its ramified structure, the emotional and subjective pattern.
So the best form of its realization is text, in our case public speech, and schemas, because in such way the interlocutor or listener may feel the person, absorb his or her experience, make conclusions, reveal hidden subtext or veiled value of expressions, share emotions and to get inspiration, the most important thing.

It is an idioconcept because it concerns each person's mind and vied through their world understanding, on which affected age, gender, presence or absence of education, character, the level of life in general, marital status and surrounding. Accordingly, it can be assumed that individuals understand this conception from their own point of view. They can arise inspiration independently, because of social influence or real prototype represented by celebrities, book or film characters or other famous representatives from distinct domains.

In consonance with M. Pimenova' classification the concept of MOTIVATION is a basic one that includes the psychological phenomenon of growing, reaching success, obtain desirable results, setting and going to the peak, putting afford to accomplish things, becoming a better version of yourself, earning certain skills in the specific domain, becoming professional and well-educated, etc.

Conclusions. In compliance with value-sociological parameters, the concept MOTIVATION is a spiritual phenomenon, since it denotes the psychological notion or even visible or hidden personal desire towards one's own life, also we characterize it as the abstract term since we cannot touch, smell, taste, see it. The only thing that we can do in terms of motivation, is to nature it in our mind and become mature to take action.

\section{BIBLIOGRAPHY}

1. Воркачев С.Г. Счастье как лингвокультурный концепт. Москва: Гнозис, 2004. 236 с.

2. Жаботинська С.А. Концептуальный анализ языка: фреймовые сети. Мова. Науково-теоретичний часопис із мовознавства. № 9: Проблеми прикладної лінгвістики. / Під ред. Іщенко Д.С. Одеса: Астропринт, 2004. С. 81-92.

3. Карасик В.И. Языковой круг: личность, концепты, дискурс. Волгоград: Перемена, 2002. 477 с.

4. Манакін В.М. Мова і міжкультурна комунікація: навч.посібник. Київ: “Академія”, 2012. 288 с.

5. Кубрякова О.С., Демьянков В.3., Панкрац Ю.Т. Краткий словарь когнитивних терминов. Москва: Русские словари, 1996. 245 с.

6. Мартинюк А.П. Словник основних термінів когнітивно-дискурсивної лінгвістики. Харків: ХНУ імені В. Н. Каразіна, 2011. 196 с.

7. Попова З.Д., Стернин И.А. Язык и сознание: теоретические разграничения и понятийный аппарат. Язык и нащиональное сознание. Вопросы теории и методологии. Воронеж : ВГУ, 2002. С. 8-50.

8. Приходько А.М. Концепти і концептосистеми в когнітивно-дискурсивній парадигмі лінгвістики. Запоріжжя: Прем'єр, 2008. 331 с.

9. Пименова М.В. Типы концептов и этапы концептуального исследования. Вестник Кемеровского государственного университета. Кемерово, 2013. Вып. 2(54). Т. 2. С. 127-131.

10. Селіванова О.О. Світ свідомості в мові. Мир сознания в языке : монографічне видання. Черкаси : Ю. Чабаненко, 2012. $488 \mathrm{c}$.

11. Степанов Ю.С. Концепты. Тонкая пленка цивилизации. Москва: Языки русской культуры, 2007. 248 с.

12. Bandura A. Self-regulation of motivation through anticipatory and self-reactive mechanisms. Perspectives on motivation: Nebraska symposium on motivation. Lincoln, NE: University of Nebraska Press, 1991. Vol. 38. P. 69-164.

13. 13.Croft W., Alan Cruse D. Cognitive Linguistics. London: Cambridge University Press, 2004. 356 pp.

14. Dąbrowska E. Handbook of cognitive linguistics. Berlin: De Gruyter, 2015. 716 pp. 
15. Deci E.L., Ryan R. Self-determination theory and the facilitation of intrinsic motivation, social development, and well-being. American Psychologist. 2000. 55(1). P. 68-78

16. Gorman P. Motivation and Emotion. London: Routledge, 2004. 126 pp.

17. Hoffman, B. Motivation for Learning and Performance. Florida: Elsevier Science \& Technology, 2015. 399 pp.

18. Jackendoff R. The Architecture of the Language Faculty. Computational Linguistics. Cambridge: MA: The MIT Press, 1997. P. 652-655

19. Johnson, Mark L. The Body in the Mind: The Bodily Basis of Meaning, Imagination, and Reason. Chicago: University of Chicago Press, 1987. 272 pp.

20. Lakoff G. and Johnson M. Metaphors We Live By. Chicago; London: The University of Chicago Press, 1980.242 pp.

21. Fillmore C. J. Frames and the semantics of understanding. Quaderni di Semantica. 1985. Vol. 6, No. 2. $222-254$ pp.

22. Lakoff G. Women, Fire and Dangerous Things: What Categories Reveal about the Mind. Chicago and London:

The University of Chicago Press, 1987. pp. 605

23. Lewandowska-Tomaszczyk B. Conceptualizations of Time. Amsterdam: John Benjamins publishing compony, 2016. $325 \mathrm{pp}$.

24. Maslow A. H. Motivation and personality. 2nd ed. New York: Harper \& Row, 1970. 360 pp.

25. Online Dictionaries. Word Reference. URL: https:/www.wordreference.com/definition/-tion (дата звернення 25.05.2021)

26. Online etymological dictionary. URL: https://www.etymonline.com/word/motivate (дата звернення 25. 05. 2021)

27. Ortolang. URL: https://www.cnrtl.fr/definition/motiver (дата звернення 25. 05. 2021)

28. Radden G., Panther, K.-U. Introduction: Reflections on motivation. Studies in linguistic motivation.Cognitive Linguistics Research 28. Berlin and New York: Mouton de Gruyter, 2004. 1-46 pp.

29. Langacker R. W. Foundations of Cognitive Grammar: Volume II. Stanford: Stanford University Press, 1991.591 pp.

30. Saussure F. Course in General Linguistics. New York, Toronto, London: McGraw-Hill, 1959.133 pp.

31. Stanovich K. E. How to think straight about psychology (10th edition). Boston: MA: Pearson, 2013. 257 pp.

32. Tabakowska E. Athanasiadou A. Speaking of emotions conceptualisation and expression. Berlin: De Gruyter Mouton, $2010.440 \mathrm{pp}$.

33. Taylor J. R. Cognitive Grammar. Oxford, New York : Oxford University Press, 2002. 621 pp.

34. The Merriam-Webster dictionary. URL: https://www.merriam-webster.com/dictionary/motivation\#learn-more (дата звернення 25. 05. 2021)

35. Wierzbicka A. Semantics, culture, and cognition: Universal human concepts in culture-specific configurations. Oxford \& New York: Oxford University Press, 1992. 487 pp.

36. Word Sense Dictionary. URL: https://www.wordsense.eu/movere/ (дата звернення 25. 05. 2021)

\section{REFERENCES}

1. Vorkachev S. G. Schaste kak lingvokulturnyj koncept [Happiness as a linguocultural concept]. Moscow: Gnozis, 2004. 236 pp. [in Russian]

2. Zhabotynska S.A. Kontseptualnyiy analiz yazyika: freymovyie seti [Conceptual analysis of language: frame networks]. Language. Scientific and theoretical journal of linguistics. № 9: Problems of Applied Linguistics / ed. Ishchenko D. S. Odessa: Astroprint, 2004. P. 81-92. [in Russian]

3. Karasik V.I. Yazykovoj krug: lichnost, koncepty, diskurs [Language circle: personality, concepts, discourse]. Volgograd: Peremena, 2002. 288 pp. [in Russian]

4. Manakin V.M. Mova i mizhkulturna komunikatsiia: navch.posibnyk [Language and intercultural communication: textbook]. Kyiv: "Academy”, 2012. 288 pp. [in Ukrainian]

5. Kubryakova O.S., Demyankov V.Z., Pankracz Y.T. Kratkij slovar kognitivnix terminov [A Brief Dictionary of Cognitive Terms]. Moscow: Russian dictionaries, 1996. 245 pp. [in Russian]

6. Martyniuk A.P. Slovnyk osnovnykh terminiv kohnityvno-dyskursyvnoi linhvistyky [Dictionary of basic terms of cognitive-discursive linguistics]. Kharkiv: KhNU named after V. N. Karazin, 2011. 196 pp. [in Ukrainian]

7. Popova Z.D., Sternin I.A. Yazyk i soznanie: teoreticheskie razgranicheniya i ponyatijnyj apparat [Language and Consciousness: Theoretical Delimitation and Conceptual Apparatus]. Language and national consciousness. Questions of theory and methodology. Voronezh: Voronezh State University, 2002. P. 8-50. [in Russian]

8. Prykhodko A.M. Kontsepty i kontseptosystemy v kohnityvno-dyskursyvnii paradyhmi linhvistyky [Concepts and conceptual systems in the cognitive-discursive paradigm of linguistics]. Zaporizhzhia: Premier, 2008. $331 \mathrm{pp}$. [in Ukrainian]

9. Pimenova M.V. Tipy konceptov i etapy konceptualnogo issledovaniya [Types of concepts and stages of conceptual research]. Bulletin of the Kemerovo State University. Kemerovo, 2013. Issue. 2 (54). V. 2. P. 127-131. [in Russian]

10. Selivanova O.O. Svit svidomosti v movi. Mir soznaniya v yazyike: monohrafichne vydannia [The world of consciousness in language : a monographic edition]. Cherkasy : Y. Chabanenko, 2012. 488 pp. [in Ukrainian]

11. Stepanov Y.S. Koncepty. Tonkaya plenka civilizacii. [Concepts. Thin film of civilization]. Moscow: Languages of Russian culture, 2007. 248 pp.

12. Bandura A. Self-regulation of motivation through anticipatory and self-reactive mechanisms. Perspectives on motivation: Nebraska symposium on motivation. Lincoln, NE: University of Nebraska Press, 1991. Vol. 38. P. 69-164 [in English]

13. Croft W., Alan Cruse D. Cognitive Linguistics. London: Cambridge University Press, 2004. 356 pp. [in English]

14. Dąbrowska E. Handbook of cognitive linguistics. Berlin: De Gruyter, 2015. 716 pp. [in English] 
15. Deci E.L., Ryan R. Self-determination theory and the facilitation of intrinsic motivation, social development, and well-being. American Psychologist. 2000. 55(1). P. 68-78 [in English]

16. Gorman P. Motivation and Emotion. London: Routledge, 2004. 126 pp. [in English]

17. Hoffman, B. Motivation for Learning and Performance. Florida: Elsevier Science \& Technology, 2015. 399 pp. [in English]

18. Jackendoff R. The Architecture of the Language Faculty. Computational Linguistics. Cambridge: MA: The MIT Press, 1997. P. $652-655$ [in English]

19. Johnson, Mark L. The Body in the Mind: The Bodily Basis of Meaning, Imagination, and Reason. Chicago: University of Chicago Press, 1987. 272 pp. [in English]

20. Lakoff G. and Johnson M. Metaphors We Live By. Chicago; London: The University of Chicago Press, 1980. 242 pp. [in English]

21. Fillmore C.J. Frames and the semantics of understanding. Quaderni di Semantica. 1985. Vol. 6, No. 2. 222-254 pp. [in English]

22. Lakoff G. Women, Fire and Dangerous Things: What Categories Reveal about the Mind. Chicago and London: The University of Chicago Press, 1987. pp. 605 [in English]

23. Lewandowska-Tomaszczyk B. Conceptualizations of Time. Amsterdam: John Benjamin's publishing company, 2016. 325 pp. [in English]

24. Maslow A.H. Motivation and personality. 2nd ed. New York: Harper \& Row, 1970. 360 pp. [in English]

25. Online Dictionaries. Word Reference. URL: https://www.wordreference.com/definition/-tion (дата звернення 25.05.2021) [in English]

26. Online etymological dictionary. URL : https://www.etymonline.com/word/motivate (дата звернення 25.05.2021) [in English]

27. Ortolang. URL: https://www.cnrtl.fr/definition/motiver (дата звернення 25.05.2021) [in English]

28. Radden G., Panther, K.-U. Introduction: Reflections on motivation. Studies in linguistic motivation.Cognitive Linguistics Research 28. Berlin and New York: Mouton de Gruyter, 2004. 1-46 pp. [in English]

29. Langacker R.W. Foundations of Cognitive Grammar: Volume II. Stanford: Stanford University Press, 1991. 591 pp. [in English]

30. Saussure F. Course in General Linguistics. New York, Toronto, London: McGraw-Hill, 1959.133 pp. [in English]

31. Stanovich K.E. How to think straight about psychology (10th edition). Boston: MA: Pearson, 2013.257 pp. [in English]

32. Tabakowska E. Athanasiadou A. Speaking of emotions conceptualization and expression. Berlin: De Gruyter Mouton, 2010. 440 pp. [in English]

33.Taylor J.R. Cognitive Grammar. Oxford, New York: Oxford University Press, 2002. 621 pp. [in English]

34. The Merriam-Webster dictionary. URL: https://www.merriam-webster.com/dictionary/motivation\#learn-more (дата звернення 25. 05. 2021) [in English]

35. Wierzbicka A. Semantics, culture, and cognition: Universal human concepts in culture-specific configurations. Oxford \& New York: Oxford University Press, 1992. 487 pp. [in English]

36. Word Sense Dictionary. URL: https://www.wordsense.eu/movere/ (дата звернення 25. 05. 2021) [in English] 